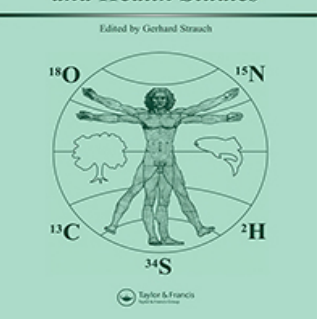

\title{
Controls over spatial and seasonal variations on isotopic composition of the precipitation along the central and eastern portion of Brazil
}

Didier Gastmans, Vinícius Santos, Juliana Aparecida Galhardi, João Felipe Gromboni, Ludmila Vianna Batista, Konrad Miotlinski, Hung Kiang Chang \& José Silvio Govone

To cite this article: Didier Gastmans, Vinícius Santos, Juliana Aparecida Galhardi, João Felipe Gromboni, Ludmila Vianna Batista, Konrad Miotlinski, Hung Kiang Chang \& José Silvio Govone (2017) Controls over spatial and seasonal variations on isotopic composition of the precipitation along the central and eastern portion of Brazil, Isotopes in Environmental and Health Studies, 53:5, 518-538, DOI: $10.1080 / 10256016.2017 .1305376$

To link to this article: https://doi.org/10.1080/10256016.2017.1305376

+ View supplementary material $\widetilde{T}$

Submit your article to this journal $₫$
Published online: 26 Apr 2017. 


\title{
Controls over spatial and seasonal variations on isotopic composition of the precipitation along the central and eastern portion of Brazil
}

\author{
Didier Gastmans (D) ${ }^{a}$, Vinícius Santos ${ }^{a}$, Juliana Aparecida Galhardi ${ }^{a}$, \\ João Felipe Gromboni ${ }^{a}$, Ludmila Vianna Batista ${ }^{a}$, Konrad Miotlinski ${ }^{b}$, \\ Hung Kiang Chang ${ }^{b}$ and José Silvio Govone ${ }^{a}$

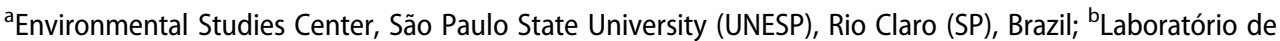 \\ Estudos de Bacias, Institute of Geosciences and Exact Sciences, São Paulo State University (UNESP), Rio Claro \\ (SP), Brazil
}

\begin{abstract}
Based on Global Network Isotopes in Precipitation (GNIP) isotopic data set, a review of the spatial and temporal variability of $\delta^{18} \mathrm{O}$ and $\delta^{2} \mathrm{H}$ in precipitation was conducted throughout central and eastern Brazil, indicating that dynamic interactions between Intertropical and South Atlantic Convergence Zones, Amazon rainforest, and Atlantic Ocean determine the variations on the isotopic composition of precipitation over this area. Despite the seasonality and latitude effects observed, a fair correlation with precipitation amount was found. In addition, Hybrid Single-Particle Lagrangian Integrated Trajectory (HYSPLIT) air mass back trajectories were used to quantify the factors controlling daily variability in stable isotopes in precipitation. Through a linear multiple regression analysis, it was observed that temporal variations were consistent with the meteorological parameters derived from HYSPLIT, particularly precipitation amount along the trajectory and mix depth, but are not dependent on vapour residence time in the atmosphere. These findings also indicate the importance of convective systems to control the isotopic composition of precipitation in tropical and subtropical regions.
\end{abstract}

\section{ARTICLE HISTORY}

Received 12 August 2016 Accepted 27 January 2017

\section{KEYWORDS}

Brazilian climate; deuterium excess; hydrogen-2; isotope hydrology; multiple regression model; oxygen-18; precipitation

\section{Introduction}

Forecasts of natural and future anthropogenic impacts on climate affecting fresh water depend on a better understanding of the factors controlling regionalized precipitation regimes. This is especially important in tropical areas, where the complexities of atmospheric circulation and the water cycle's seasonal intensity limit our capacity to predict changes in precipitation patterns and water availability. Associated with the effects of global warming and the increase in greenhouse gases emission, some climatic extreme events have been observed in South America. Examples of these changes are, among 
others, the extreme droughts in the Amazonia region and in southern Brazil since 2006 and the occurrence of hurricanes in Santa Catarina in 2004 [1-3].

Stable isotopes in precipitation have been used for a long time as a useful tracer to the water cycle, and it has become an important tool for understanding climatic factors that affect precipitation regimes. Spatial variations on stable isotope composition of precipitation are directly related to the movement of air masses and fractionation during water phase changes, imprinting a directional spatial pattern across the globe [4]. Since the beginning of regular measurements of stable isotope composition in precipitation, some patterns have been correlated to a few dominant processes, as temperature effect due to phase changes and Rayleigh-type isotope fractionation as a result of rainout [5-7].

In tropical regions, the link between climate and isotopic composition in precipitation is not as well established as in temperate climates, where stable isotopic variations in precipitation have been quite well correlated with fluctuations in mean air temperature $[6,8-10]$. The response in stable isotope content in precipitation due to temperature variations is not observed in tropical regions, due to low variations in air temperature seasonality. On the other hand, several studies from tropical regions have reported a negative correlation between isotopic content and precipitation amount, called 'amount effect', considering monthly composite samples $[6,8,11]$. This phenomenon is related to the rain-out process of convective and stratiform precipitation. The evaluation of daily and eventbased samples from precipitation in tropical regions has not indicated a relationship between precipitation amount and isotopic composition of precipitation [12-14], that could be associated to the major occurence of fractionation process on tropical precipitation along the vertical profile [15].

These differences in vertical air motion and microphysical processes governing rain formation lead to two types of precipitation: convective or stratiform rains. Recently, Aggarwal et al. [16] have shown that the isotopic composition of precipitation is related to the rain-type proportion, and more depleted values represent an increase in stratiform proportions in precipitation.

Recently, the use of isotope-equipped atmospheric general circulation models allowed to reproduce reasonably well the global distribution of mean annual isotope contents of modern precipitation, but failed to explain observed seasonal or inter-annual variations on a regional or local scale, and some discrepancies were observed with respect to the established relationships in terms of mean surface air temperature at mid-to-high latitudes, or with the amount of precipitation in tropical areas [17]. This may be, at least in part, attributed to the fact that both the temperature and amount dependencies of isotopes are influenced by moisture source and transport patterns [17].

Between the 1960s and the 1980s, about 200 stations of the global network of isotopes in precipitation (GNIP) were providing monthly precipitation samples for isotope analysis which included 15-20 stations in Brazil [8]. However, the majority of the Brazilian stations were decommissioned in the 1980s and the 1990s. Unfortunately, this loss of the Brazilian stations made a significant impact on the isotope coverage of GNIP stations in South America. Based on isotopic data sets provided by GNIP stations in the Brazilian territory, some important studies have been carried out, showing the importance of the recirculation of water related to evaporation and evapotranspiration over the Amazon Basin [1820]. Along the Atlantic coast, observed variations in the monthly isotopic composition of 
precipitation are related to variations in moisture sources, due to seasonal changes in the atmospheric circulation patterns [18-20].

The main purpose of this paper is to review the historical information on stable isotopic composition of the precipitation over the central and eastern part of Brazil, based on monthly and daily observations from GNIP stations, and to identify the main group of climatic factors responsible for the observed changes in the isotopic content in precipitation. Furthermore, at local scale, daily isotope variations in Rio Claro (São Paulo), Southeast Brazil derived from observations measured during one year (from February 2014 to February2015) were analysed in combination with surface meteorological data and HYbrid Single-Particle Lagrangian Integrated Trajectory (HYSPLIT) air masses back trajectories [21] to determine the possible key drivers of isotope variations using a multiple regression model.

\section{Precipitation and stable isotopes over Brazil}

The large territorial extent of the central-eastern portion of Brazil, associated with the diversity of relief forms, is responsible for the development of distinct atmospheric circulation systems, contributing for the spatial and temporal variability observed in precipitation [22]. Most of the precipitation is related to the austral summer season (DecemberJanuary-February) (Figure 1), except in the northernmost and southernmost parts of the country. In NE Brazil, the maximum of precipitation is observed during austral autumn and winter, related to the annual migration of deep tropical convection, while southern Brazil shows a uniform distribution of precipitation throughout the year [23].

NE Brazil is characterized by two distinct precipitation regimes: (1) Along the coastal zone, annual precipitation is about $1500 \mathrm{~mm}$ per year and dominates in the wintertime, (2) whereas the region further from the coast is characterized by semi-arid climate presenting an annual precipitation amount of less than $500 \mathrm{~mm}$ per year and dominating in the summertime [22]. Despite these variations, the climate in NE Brazil is dominated by the meridional migration of the Intertropical Convergence Zone (ITCZ), which in turn, controls the dynamics of the trade winds over oceans and land masses. The austral autumn maximum in precipitation in NE Brazil is connected to the southward penetration of the ITCZ into the tropical South Atlantic Ocean during this season [23]. Three GNIP stations (Ceará Mirim, Fortaleza, and Salvador) are located in the coastal zone and five stations in the semi-arid region (Carolina, Betânia, Fazenda Conceição, Floresta and Serra Talhada).

In the SE and central parts of Brazil, tropical and extratropical air masses interact intensively, establishing important constrains on precipitation over this region. This includes the change in moisture sources related to a seasonal shift from a more monsoonal regime during the summer to a more extratropical regime in the winter. Due to this change, precipitation during the summer season over this region is controlled by the South American Summer Monsoon (SASM), which is established during the summer months (DecemberJanuary-February). On the other hand, an extratropical circulation regime is responsible for a significant fraction of the regional precipitation during the winter and early spring seasons (May to September), especially south of the $30^{\circ} \mathrm{S}$ [22].

During the summer season, when the SASM is active, more than $50 \%$ of the annual precipitation falls [24,25], and a NW-SE elongated band of enhanced convective activity emanates from the Amazon Basin and extends into subtropical latitudes and over the Atlantic 


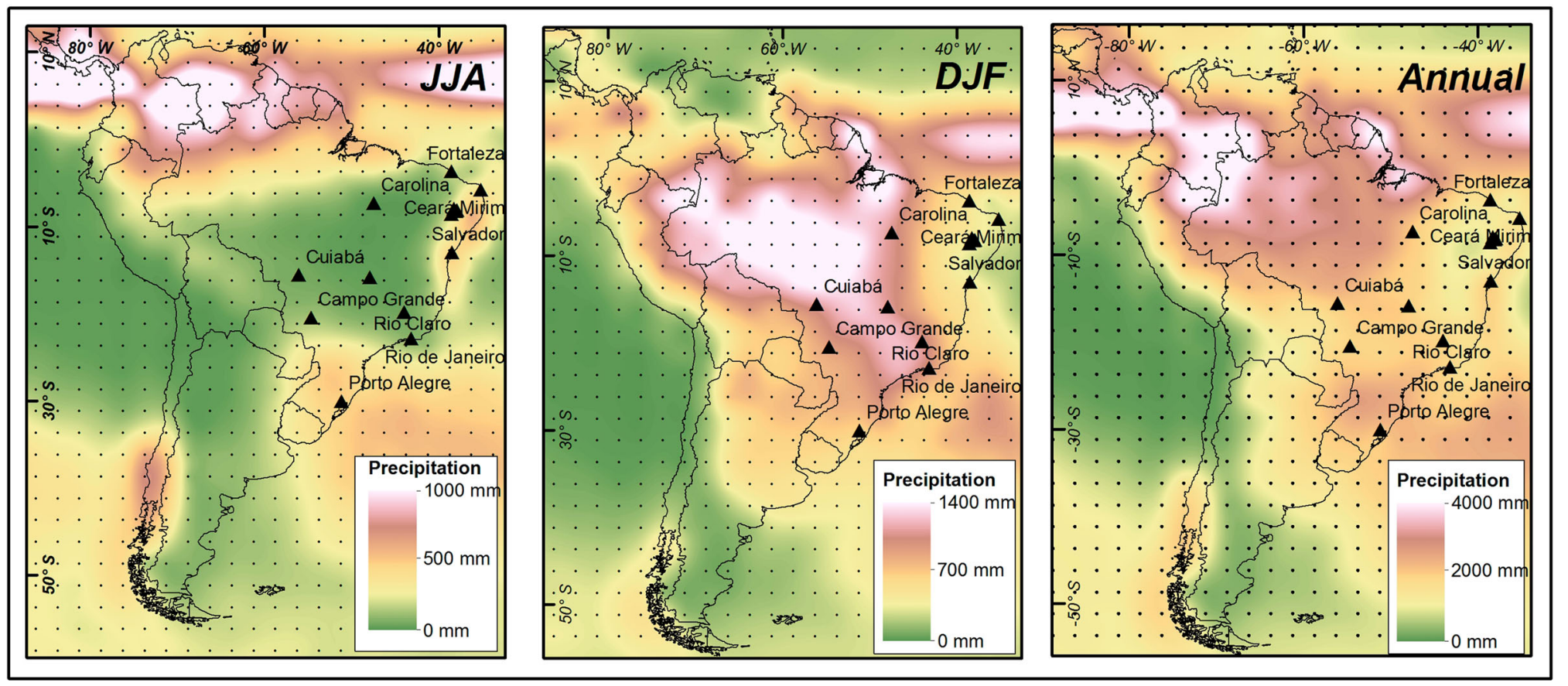

Figure 1. Seasonal precipitation totals (in $\mathrm{mm}$ ) for June/July/August (left), December/January/February (centre) and Annual values (right) based on a long-term mean (1990-2010) from the dataset of Climate Prediction centre- Mmerged analysis of precipitation (CMAP), available at [24] and in [25]. The location of the GNIP Stations is depicted as triangles. 
coast, in which the South Atlantic Convergence Zone (SACZ) is established [26]. At the centre of the SACZ, where the GNIP stations of Cuiabá, Brasília, Campo Grande, Rio de Janeiro and Belo Horizonte are situated, the SASM is responsible for $80 \%$ of the annual precipitation (Figure 1).

The rainfall related to this monsoonal system normally presents depleted values of $\delta^{18} \mathrm{O}$, due to the incorporation and transport of a high fraction of moisture coming from Amazon Basin towards the Brazilian subtropics by the South American low-level jet, which presents more depleted values for $\delta^{18} \mathrm{O}$. Isotopic composition of precipitation along the SACZ tends to be proportional to the degree of rainout of $\delta^{18} \mathrm{O}$ over the Amazon Basin, which is enhanced during more intense phases of the SASM [26,27].

Evaluation of temporal variations in isotopic composition of precipitation collected at Cuiabá GNIP station, located in the Brazilian central zone, has revealed that during the active period of the $S A C Z$, more depleted values observed in precipitation were associated with the precipitation amount and the occurrence of storm precipitation, while during the inactive period of the $S A C Z$, a weakening of the vapour flux coming from the Amazon basin was observed $[28,29]$.

Most of the precipitation during winter and early spring, especially south of the $30^{\circ} \mathrm{S}$ along the Atlantic coast of Brazil, is due to the extratropical circulation regime, as a result of migratory cyclones along the subtropical Atlantic coast [30,31]. Isotopic composition of the precipitation related to these events tends to present relatively high values of $\delta^{18} \mathrm{O}$, due to the incorporation of large amounts of moisture derived from the Atlantic Ocean [32].

Significant variations in intensity and spatial extent of precipitation over the Brazilian territory on an interannual basis are affected by numerous factors acting over the region, including: variation on tropical Atlantic sea surface temperature [33-36], the El Niño-Southern Oscilation [23, 37-40], land surface conditions such as soil moisture or vegetation cover [41, 42], and interactions with the extratropical circulation [43-45].

\section{Data and methods}

Stable isotope $\left(\delta^{18} \mathrm{O}\right.$ and $\left.\delta^{2} \mathrm{H}\right)$ data from 15 GNIP stations located in central, SE and S Brazil were analysed to obtain an overview about the spatial and temporal distribution of isotopic composition of precipitation. The dataset was obtained from the GNIP database [46], representing monthly samples. These stations were operating during different periods from the 1950s until the 1990s, with the exception of the Belo Horizonte station, operative since 2010, and Rio Claro station, operative since 2014 (Table 1 and Figure 2).

Based on climatic regions defined by Reboita et al. [22], the data from GNIP stations were divided into three major groups: Group 1 encompassing stations in NE Brazil (Fortaleza, Ceará Mirim, Salvador, Carolina, Betania [Met Station], Betania [Fazenda Conceição], Serra Talhada and Floresta), Group 2 covering the central part of Brazil (Brasília, Belo Horizonte, Rio de Janeiro, Campo Grande, Cuiabá and Rio Claro); Group 3 representing the south of Brazil (Porto Alegre) (Figure 2).

Precipitation collection for these stations has followed the technical procedures for GNIP stations proposed by the IAEA [47] and is associated with isotopic composition information; the reports include meteorological information such as monthly temperature, precipitation amount and vapour pressure data. Determination of the isotopic composition of 
Table 1. Details of the GNIP Stations in NE, SE and S Brazil. Isotope values in \%o.

\begin{tabular}{|c|c|c|c|c|c|c|c|c|c|c|c|c|c|}
\hline \multirow{2}{*}{$\begin{array}{l}\text { GNIP } \\
\text { Code }\end{array}$} & \multirow[b]{2}{*}{ Station } & \multirow[b]{2}{*}{ Latitude } & \multirow[b]{2}{*}{ Longitude } & \multirow[b]{2}{*}{ Climate } & \multirow{2}{*}{$\begin{array}{l}\text { Elevation } \\
\quad(\mathrm{m})\end{array}$} & \multirow[b]{2}{*}{ Period } & \multirow[b]{2}{*}{$n$} & \multirow[b]{2}{*}{ LMWL } & \multicolumn{2}{|c|}{ Arithmetic means } & \multicolumn{3}{|c|}{ Weighted means } \\
\hline & & & & & & & & & $\delta^{18} \mathrm{O}$ & $\delta^{2} \mathrm{H}$ & $\delta^{18} \mathrm{O}$ & $\delta^{2} \mathrm{H}$ & $d$-excess \\
\hline 8239700 & Fortaleza & $\begin{array}{l}-3^{\circ} 43^{\prime} \\
12^{\prime \prime}\end{array}$ & $\begin{array}{l}-38^{\circ} 33^{\prime} \\
00^{\prime \prime}\end{array}$ & As & 27 & $\begin{array}{r}1965- \\
1987\end{array}$ & $276^{\mathrm{a}}$ & $\begin{array}{c}\delta^{2} \mathrm{H}=7.63 \\
\delta^{18} \mathrm{O}+9.17\end{array}$ & $-1.78 \pm 0.50$ & $-3.38 \pm 4.21$ & $-2.38 \pm 0.73$ & $-8.86 \pm 6.61$ & $8.95 \pm 3.35$ \\
\hline 8259800 & Ceará Mirim & $\begin{array}{l}-5^{\circ} 48^{\prime} \\
0^{\prime \prime}\end{array}$ & $\begin{array}{c}-35^{\circ} 12^{\prime} \\
00^{\prime \prime}\end{array}$ & As & 8 & $\begin{array}{r}1961- \\
1983\end{array}$ & $276^{a}$ & $\begin{array}{l}\delta^{2} \mathrm{H}=7.30 \\
\delta^{18} \mathrm{O}+8.56\end{array}$ & $-1.58 \pm 0.31$ & $-3.07 \pm 3.14$ & $-2.19 \pm 0.64$ & $-8.04 \pm 4.89$ & $10.87 \pm 2.10$ \\
\hline 8322900 & $\begin{array}{l}\text { Salvador } \\
\text { (Ondina) }\end{array}$ & $\begin{array}{c}-13^{\circ} 0^{\prime} \\
00^{\prime \prime}\end{array}$ & $\begin{array}{c}-38^{\circ} 31^{\prime} \\
12^{\prime \prime}\end{array}$ & Af & 45 & $\begin{array}{r}1965- \\
1987\end{array}$ & $276^{a}$ & $\begin{array}{l}\delta^{2} \mathrm{H}=7.81 \\
\quad \delta^{18} \mathrm{O}+10.44\end{array}$ & $-1.42 \pm 0.28$ & $-0.61 \pm 3.27$ & $-1.65 \pm 0.36$ & $-1.93 \pm 3.29$ & $11.70 \pm 1.84$ \\
\hline 8337800 & $\begin{array}{l}\text { Brasília } \\
\quad \text { (Airport) }\end{array}$ & $\begin{array}{l}-15^{\circ} 51^{\prime} \\
0^{\prime \prime}\end{array}$ & $\begin{array}{l}-47^{\circ} 55^{\prime} \\
48^{\prime \prime}\end{array}$ & Aw & 1061 & $\begin{array}{r}1963- \\
1987\end{array}$ & $300^{\mathrm{a}}$ & $\begin{array}{l}\delta^{2} H=7.75 \\
\delta^{18} O+10.48\end{array}$ & $-3.98 \pm 0.82$ & $-21.71 \pm 6.44$ & $-4.87 \pm 1.14$ & $-29.20 \pm 8.52$ & $11.19 \pm 3.11$ \\
\hline 8358301 & $\begin{array}{l}\text { Belo Horizonte } \\
\text { (CDTN) }\end{array}$ & $\begin{array}{l}-19^{\circ} 52^{\prime} \\
15^{\prime \prime}\end{array}$ & $\begin{array}{l}-43^{\circ} 58^{\prime} \\
02^{\prime \prime}\end{array}$ & Aw & 857 & $\begin{array}{r}2008- \\
2013\end{array}$ & $72^{\mathrm{a}}$ & $\begin{array}{l}\delta^{2} \mathrm{H}=8.02 \\
\quad \delta^{18} \mathrm{O}+12.79\end{array}$ & $-5.69 \pm 1.65$ & $-32.88 \pm 12.97$ & $-6.26 \pm 1.97$ & $-37.49 \pm 15.64$ & $12.58 \pm 0.70$ \\
\hline 8374300 & Rio de Janeiro & $\begin{array}{l}-22^{\circ} 54^{\prime} \\
0^{\prime \prime}\end{array}$ & $\begin{array}{c}-43^{\circ} 10^{\prime} \\
12^{\prime \prime}\end{array}$ & Af & 26 & $\begin{array}{r}1961- \\
1987\end{array}$ & $324^{a}$ & $\begin{array}{l}\delta^{2} \mathrm{H}=7.98 \\
\delta^{18} \mathrm{O}+12.34\end{array}$ & $-3.81 \pm 0.71$ & $-18.32 \pm 6.00$ & $-4.34 \pm 1.11$ & $-24.20 \pm 9.27$ & $11.80 \pm 1.96$ \\
\hline 8361201 & Campo Grande & $\begin{array}{l}-20^{\circ} 28^{\prime} \\
12^{\prime \prime}\end{array}$ & $\begin{array}{c}-54^{\circ} 40^{\prime} \\
12^{\prime \prime}\end{array}$ & Aw & 572 & $\begin{array}{r}1973- \\
1979\end{array}$ & $64^{\mathrm{a}}$ & $\begin{array}{l}\delta^{2} H=8.09 \\
\delta^{18} O+13.31\end{array}$ & $-5.84 \pm 1.06$ & $-43.17 \pm 5.58$ & $-6.20 \pm 1.28$ & $-44.68 \pm 4.27$ & $13.24 \pm 1.75$ \\
\hline 8396700 & Porto Alegre & $\begin{array}{c}-30^{\circ} 4^{\prime} \\
48^{\prime \prime}\end{array}$ & $\begin{array}{l}-51^{\circ} 10^{\prime} \\
48^{\prime \prime}\end{array}$ & $\mathrm{Cfa}$ & 7 & $\begin{array}{r}1957- \\
1983\end{array}$ & $200^{a}$ & $\begin{array}{l}\delta^{2} \mathrm{H}=7.67 \\
\delta^{18} \mathrm{O}+10.59\end{array}$ & $-4.62 \pm 0.41$ & $-24.76 \pm 2.49$ & $-4.67 \pm 0.60$ & $-25.16 \pm 3.83$ & $12.22 \pm 3.03$ \\
\hline 8336101 & Cuiabá & $\begin{array}{l}-15^{\circ} 36^{\prime} \\
0^{\prime \prime}\end{array}$ & $\begin{array}{c}-56^{\circ} 06^{\prime} \\
00^{\prime \prime}\end{array}$ & Aw & 165 & $\begin{array}{r}1961- \\
1987\end{array}$ & $203^{a}$ & $\begin{array}{c}\delta^{2} \mathrm{H}=7.55 \\
\delta^{18} \mathrm{O}+7.88\end{array}$ & $-4.07 \pm 1.26$ & $-23.42 \pm 10.61$ & $-5.45 \pm 1.75$ & $-33.27 \pm 13.49$ & $10.30 \pm 3.97$ \\
\hline 8277101 & Carolina & $\begin{array}{l}-7^{\circ} 20^{\prime} \\
0^{\prime \prime}\end{array}$ & $\begin{array}{c}-47^{\circ} 28^{\prime} \\
00^{\prime \prime}\end{array}$ & Aw & 177 & $\begin{array}{r}1972- \\
1973\end{array}$ & $12^{\mathrm{a}}$ & $\begin{array}{l}\delta^{2} \mathrm{H}=8.05 \\
\delta^{18} \mathrm{O}+12.04\end{array}$ & $\mathrm{nc}$ & $\mathrm{nc}$ & $\mathrm{nc}$ & nc & $\mathrm{nc}$ \\
\hline 8278901 & $\begin{array}{c}\text { Betânia-Faz. } \\
\text { Conceição }\end{array}$ & $\begin{array}{l}-8^{\circ} 10^{\prime} \\
39^{\prime \prime}\end{array}$ & $\begin{array}{l}-37^{\circ} 56^{\prime} \\
47^{\prime \prime}\end{array}$ & Aw & 490 & $\begin{array}{r}1974- \\
1975\end{array}$ & $24^{\mathrm{a}}$ & $\begin{array}{l}\delta^{2} \mathrm{H}=8.37 \\
\quad \delta^{18} \mathrm{O}+11.25\end{array}$ & $-3.61 \pm 0.83$ & -15.50 & $-4.72 \pm 1.08$ & -18.46 & 10.75 \\
\hline 8278902 & $\begin{array}{l}\text { Betânia- } \\
\text { Met.Station }\end{array}$ & $\begin{array}{l}-8^{\circ} 15^{\prime} \\
33^{\prime \prime}\end{array}$ & $\begin{array}{c}-38^{\circ} 01^{\prime} \\
56^{\prime \prime}\end{array}$ & Aw & 450 & $\begin{array}{r}1973- \\
1975\end{array}$ & $36^{\mathrm{a}}$ & $\begin{array}{c}\delta^{2} \mathrm{H}=5.85 \\
\delta^{18} \mathrm{O}+0.27\end{array}$ & $-1.17 \pm 2.04$ & 1.20 & $-1.22 \pm 2.63$ & 1.20 & 5.20 \\
\hline 8278904 & $\begin{array}{l}\text { Serra Talhada- } \\
\text { Met.Station }\end{array}$ & $\begin{array}{c}-7^{\circ} 58^{\prime} \\
50^{\prime \prime}\end{array}$ & $\begin{array}{l}-38^{\circ} 17^{\prime} \\
33^{\prime \prime}\end{array}$ & Aw & 445 & $\begin{array}{r}1973- \\
1974\end{array}$ & $24^{\mathrm{a}}$ & $\begin{array}{c}\delta^{2} \mathrm{H}=13.76 \\
\delta^{18} \mathrm{O}+4.54\end{array}$ & $-0.74 \pm 0.49$ & $\mathrm{nc}$ & $-1.87 \pm 0.72$ & $\mathrm{nc}$ & $\mathrm{nc}$ \\
\hline 8278903 & $\begin{array}{l}\text { Floresta- } \\
\text { Met.Station }\end{array}$ & $\begin{array}{l}-8^{\circ} 35^{\prime} \\
13^{\prime \prime}\end{array}$ & $\begin{array}{c}-38^{\circ} 34^{\prime} \\
38^{\prime \prime}\end{array}$ & Aw & 320 & $\begin{array}{r}1973- \\
1975\end{array}$ & $36^{\mathrm{a}}$ & $\begin{array}{c}\delta^{2} \mathrm{H}=5.58 \\
\delta^{18} \mathrm{O}+4.63\end{array}$ & $-0.81 \pm 0.14$ & 1.50 & $-1.81 \pm 0.81$ & -2.19 & 11.01 \\
\hline 8374701 & $\begin{array}{l}\text { Rio Claro } \\
\text { (UNESP) }\end{array}$ & $\begin{array}{l}-22^{\circ} 23^{\prime} \\
57^{\prime \prime}\end{array}$ & $\begin{array}{l}-47^{\circ} 32^{\prime} \\
37^{\prime \prime}\end{array}$ & Cwa & 615 & $\begin{array}{r}2012- \\
2013\end{array}$ & $12^{\mathrm{a}}$ & $\begin{array}{l}\delta^{2} \mathrm{H}=7.98 \\
\delta^{18} \mathrm{O}+12.34\end{array}$ & $\mathrm{nc}$ & $\mathrm{nc}$ & $\mathrm{nc}$ & $\mathrm{nc}$ & $\mathrm{nc}$ \\
\hline
\end{tabular}

Obs: ${ }^{a}$ Köppen Climate classification: Af - Tropical rainforest; Aw - Tropical wet and dry; Cfa - Subtropical hot summer; Cwa - Subtropical hot summer. 


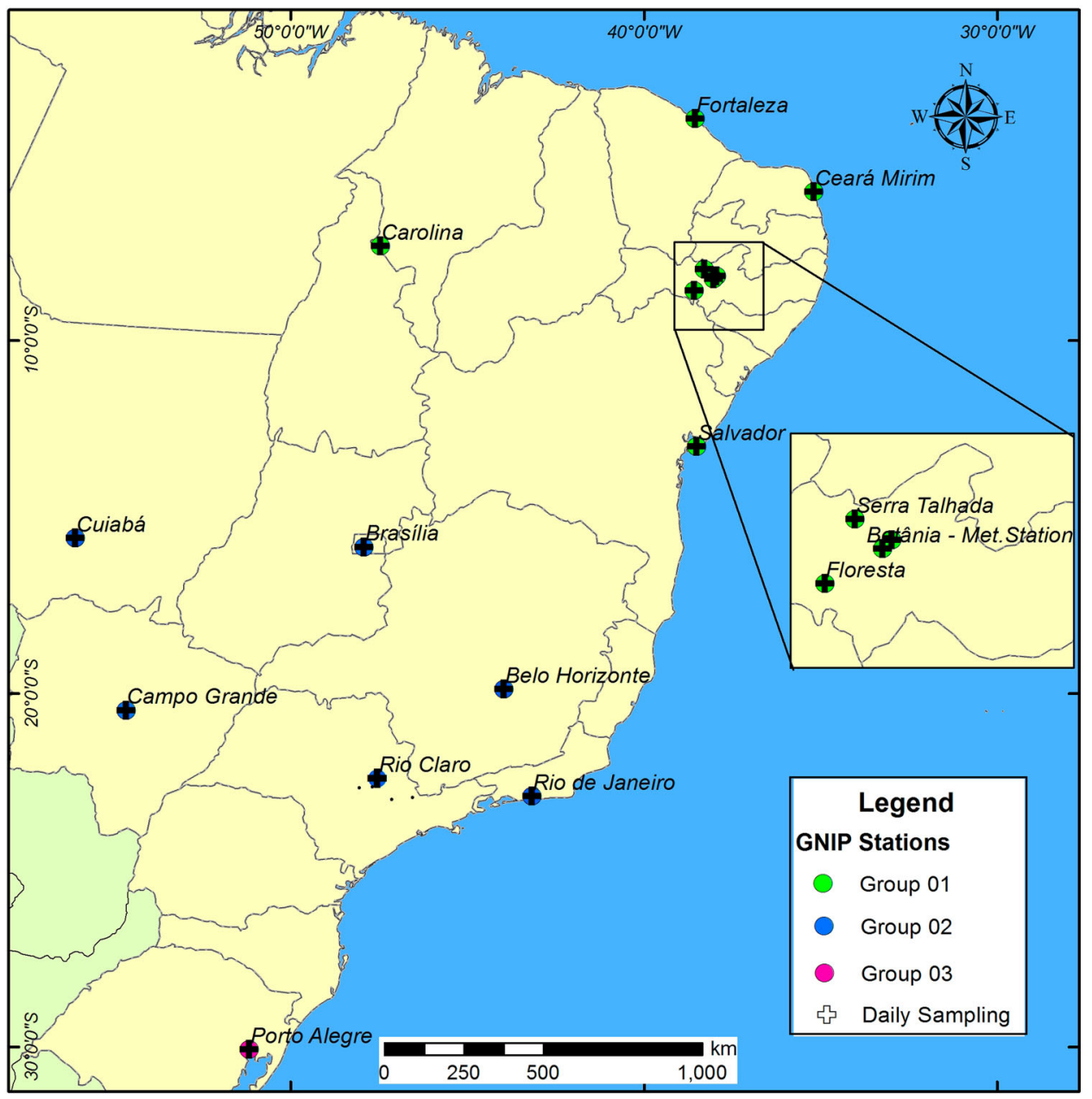

Figure 2. Map showing the GNIP stations location in the central, E and S Brazil.

precipitation was carried out in the Isotopic Hydrology Laboratories at the IAEA in Vienna or in associated laboratories; the results are expressed in delta notation ( $\delta$ ) in \%o VSMOW, and deuterium excess ( $d$-excess) calculated according the expression $d$-excess $=\delta^{2} \mathrm{H}-8$ $\delta^{18} \mathrm{O}[6]$.

Despite the different period of precipitation sampling in GNIP stations across Brazil, the observed variations in isotopic content represent a temporal average of precipitation and climatic events on a multi-annual scale, and they could be compared.

Precipitation on a daily basis was collected during one year (February 2014 to February 2015) at Rio Claro GNIP station (supplementary material, Table 1), using a Palmex rain collector [48]. Determination of isotopic composition of precipitation samples was conducted at the Laboratório de Hidrogeologia e Hidroquímica do Departamento de Geologia Aplicada IGCE/UNESP-Rio Claro, using a cavity ring down spectroscopy water isotope analyzer, Los Gatos Research. The secondary standards were: USGS-45 $\left(\delta^{2} \mathrm{H}=-10.3 \%\right.$, $\left.\delta^{18} \mathrm{O}=-2.24 \% 0\right)$, USGS-46 $\left(\delta^{2} \mathrm{H}=-236.0 \%\right.$ o, $\left.\delta^{18} \mathrm{O}=-29.80 \%\right)$, and river water (Cachoeira de Emas-CE) $\left(\delta^{2} \mathrm{H}=-36.1 \%\right.$ o, $\delta^{18} \mathrm{O}=-5.36 \%$ ). USGS standards were used 
to normalize the results to the VSMOW2-SLAP2 scale, while CE was used as a quality control and drift control standard. The analytical precision was: $\pm 1.2 \%$ o $(1 \sigma)$ for $\delta^{2} \mathrm{H}, \pm$ $0.2 \%$ o $(1 \sigma)$ for $\delta^{18} \mathrm{O}$.

Statistical analysis was carried out to test differences among the calculated local meteoric water lines (LMWLs). These tests were performed using a simple covariation analysis test (ANCOVA), which test for the equality of slopes. Just as an analysis of variance for $\mathrm{H}_{0}: \mathrm{m}_{1}=\mathrm{m}_{2}=\ldots=\mathrm{m}_{\mathrm{k}}$ assumes that all $\mathrm{k}$ population variances are equal (i.e., $\mathrm{s}_{1}^{2}=\mathrm{s}_{2}^{2}=\ldots=\mathrm{s}_{\mathrm{k}}^{2}$ ), the testing of $b_{1}=b_{2}=\ldots=b_{k}$ assumes that the residual mean squares in the $k$ populations are all the same (i.e., $\left(s_{y . x}^{2}\right)_{1}=\left(s_{y . x}^{2}\right)_{2}=\ldots . .=\left(s_{y . x}^{2}\right)_{k}[49]$.

Interpolation of monthly weighted isotopic composition from GNIP stations in Brazil, including those located in the Amazon region, were produced using a simple ArcGis [50] interpolating method denominated topo to raster, in which the interpolation is performed as inverse of the distance, the spatial continuity is preserved, the values measured are conserved, and no differences can be measured between observed and calculated values.

To complement the daily data analysis from Rio Claro GNIP station, meteorological data (precipitation, pressure, temperature and humidity) were obtained from the meteorological station located at the State University of São Paulo (UNESP) campus in Rio Claro, associated with air parcel back trajectories calculated using the HYSPLIT model [21]. The HYSPLIT model computes air mass position through time using pressure, temperature, wind speed, vertical motion and solar radiation inputs from the GDAS1 meteorological database [51]. Three data sets of single 48, 120 and $240 \mathrm{~h}$ back trajectories were calculated using the location of Rio Claro GNIP station as spatial reference, starting at 9:00 am (local time), considering air mass elevation 3000 metres over the ground, in order to represent the base of the clouds or the $0{ }^{\circ} \mathrm{C}$ level [16]. Rainfall amount along the trajectory, atmospheric pressure temperature and humidity over the point were computed through the model. Ground meteorological data are presented in the supplementary material, Table 1, combined to isotopic data. Atmospheric data derived from HYSPLIT are presented in the supplementary material, Table 2.

Based on the strength of the correlations between meteorological variables measured along back trajectories, considering different moisture residence times (48, 120 and $240 \mathrm{~h}$ ), from the ground meteorological station and the isotopic composition of precipitation $\left(\delta^{2} \mathrm{H}, \delta^{18} \mathrm{O}\right.$ and $d$-excess), a multiple regression model was developed, using stepwise regression and the Biostat software [52]. This analysis allows to choose the predictor variables presenting the strongest relationship with the dependent variables, taking into account determination coefficient, $p$-value and mean quadratic errors [52].

\section{Results and discussion}

\subsection{Monthly record - local meteoric water lines}

Despite the large temporal period covered by the precipitation monitoring programme in Brazil, different for each GNIP station, stable isotope composition of precipitation across eastern Brazil showed a wide range of values, reflecting the large variations in climatic conditions over the country (Table 1 ).

For precipitation collected in stations encompassed by Group $1(n=363)$, values for $\delta^{18} \mathrm{O}$ ranged from -8.60 to $+3.90 \%$, arithmetic mean $-1.66 \pm 0.97 \%$, weighted mean 
$-2.56 \%$ o, $\delta^{2} \mathrm{H}$ varied from -56.0 to $+19.0 \%$ o, arithmetic mean $-4.5 \pm 3.63 \%$, weighted mean $-6.8 \%$, and $d$-excess varied from -13.2 to $+23.5 \%$, arithmetic mean $9.8 \pm$ $0.52 \%$ and weighted mean $8.2 \%$. The regional meteoric water line for this group shows a regression equation of $\delta^{2} \mathrm{H}=(7.26 \pm 0.16) \delta^{18} \mathrm{O}+(8.5 \pm 0.37)(r=0.93, a=0.05$ and $n=363$ ) (Figure 3). Most of these stations are located close to the coast, and the vicinity of the moisture source reflects on value of $d$-excess $(8.55 \pm 0.37)$ lower than the global meteoric water line (GMWL). Due to the high average temperature in the NE region of Brazil, secondary evaporation under the cloud base could occur, and it should be responsible for the inclination value below 8 .

Relationship between slopes and intercept of the LMWLs from regions which have the same source of precipitation independent of the period should present a strong correlation. The values of intercept and the slope of this line are expected to represent the value of isotopic composition of precipitation falling on the GMWL; this value is expected to be close to the arithmetic mean precipitation of the region [53]. This evaluation was carried out for GNIP stations encompassed in Group 1. The results indicate the good agreement of slopes and interception for five GNIP stations in semi-arid regions; and the isotopic composition of precipitation indicates values of $-0.36 \pm 0.04 \%$ o for $\delta^{18} \mathrm{O}$, and $-4.1 \pm$ $0.44 \%$ for $\delta^{2} \mathrm{H}$, similar to values previously presented.

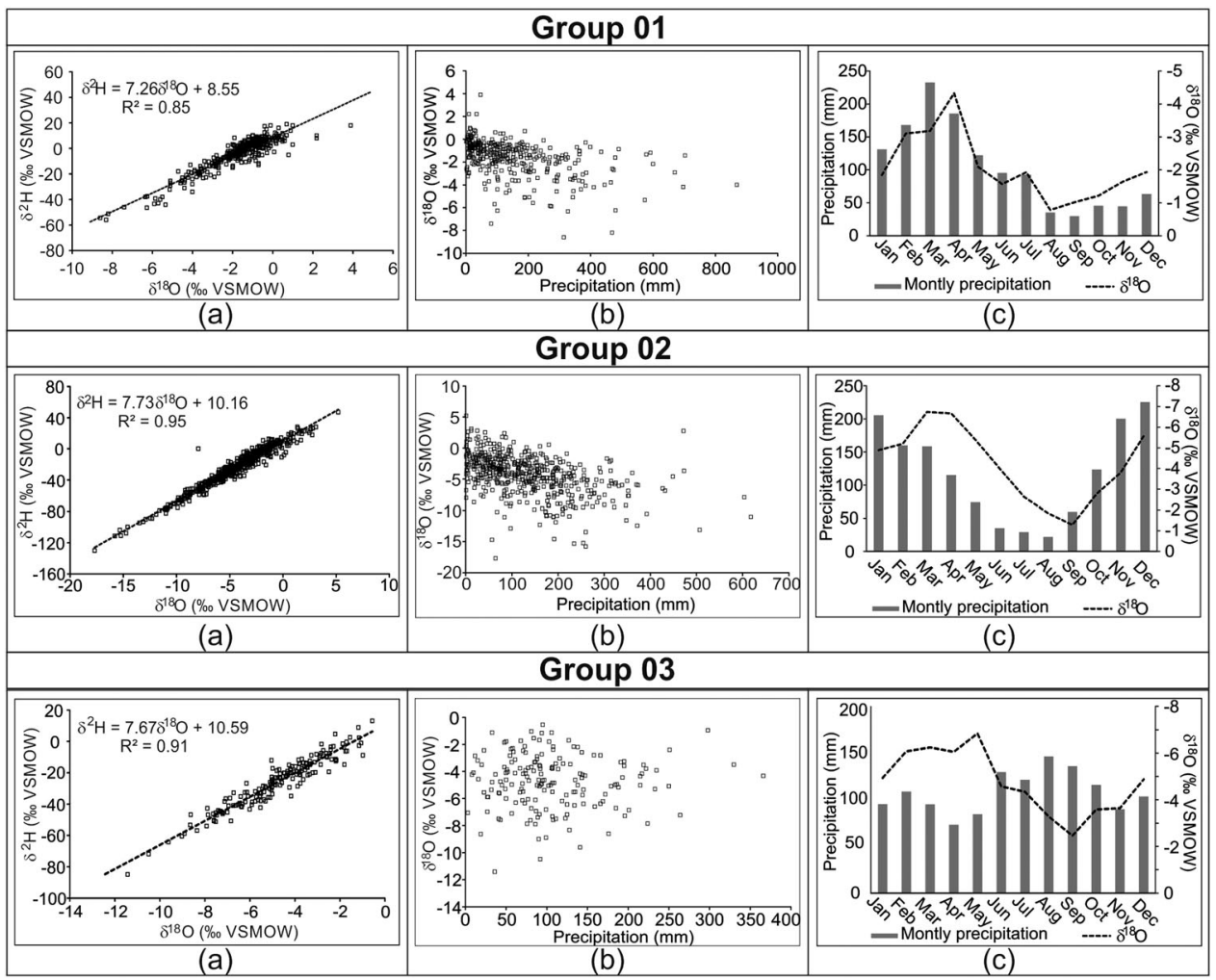

Figure 3. Isotopic variations observed for the groups of GNIP Stations located in the NE, centre and SE, and S Brazil, respectively Group 01, Group 02 and Group 03. (a) Relationship between $\delta^{18} \mathrm{O}$ and $\delta^{2} \mathrm{H}$ (Meteoric Water Line), (b) correlation between $\delta^{18} \mathrm{O}$ and precipitation amount and (c) seasonal variation in precipitation amount and $\delta^{18} \mathrm{O}$ (weighted mean). 
The isotopic composition of precipitation in central and SE Brazil (Group 2, $n=523$ ) shows $\delta^{18} \mathrm{O}$ ranging from -17.70 to $+5.20 \%$, arithmetic mean $-4.32 \pm 0.75 \%$ and weighted mean $-4.82 \%$ o. The $\delta^{2} \mathrm{H}$ varied from -130.0 to $+47.0 \%$ o, arithmetic mean $-23.1 \pm 1.10 \%$ ond weighted mean $-28.6 \%$, and the $d$-excess ranged from -9.74 to $+25.66 \%$ o, arithmetic mean $11.31 \pm 0.47 \%$ o, weighted mean $10.79 \%$ o. The regional meteoric water line for this group shows a regression equation of $\delta^{2} \mathrm{H}=$ $(7.73 \pm 0.07) \delta^{18} \mathrm{O}+(10.16 \pm 0.38)(r=0.98, a=0.05$ and $n=523)$ (Figure 3). Individual meteoric water lines for stations located in central and SE Brazil (Table 1) represent differences in climatic conditions observed along the central and southeastern part of Brazil. Inclinations of these lines are close to 8 , indicating a low evaporation effect; the interception is about 12-13 for most stations, probably due to effects of vapour recirculation along the transportation of air masses. For the Cuiabá station, the interception is about 7, this value could be associated with the proximity of this station to the moisture source located in the Amazonian region, as observed by Matsuyama et al. [29].

The relationship between slopes and interceptions of the LMWL from GNIP stations encompassed in Group 2 (Figure 4) indicates a good agreement between slopes and interception for six GNIP stations in the central part of Brazil. The isotopic composition of precipitation indicates values of $-0.10 \pm 0.005 \%$ ofor $\delta^{18} \mathrm{O}$, and $-6.7 \pm 0.06 \%$ for $\delta^{2} \mathrm{H}$, more enriched than the ones previously presented and discussed, probably due to differences in processes related to the origin of precipitation [53].

In the southern region of Brazil, a single GNIP station operated during a long period of time (Porto Alegre). Its isotopic composition of precipitation implied a $\delta^{18} \mathrm{O}$ variation from -11.43 to $-0.56 \%$, arithmetic mean $-4.76 \pm 1.98 \%$ and weighted mean $-4.76 \%$ (Group $3, n=172)$. The $\delta^{2} \mathrm{H}$ values varied from -84.9 to $+13.1 \%$, arithmetic mean $-25.9 \pm$ $15.96 \%$, and weighted mean $-25.7 \%$. The $d$-excess values varied from -1.54 to + $28.22 \%$, arithmetic mean $12.16 \pm 4.86 \%$ o and weighted mean $12.37 \%$ o. The regression

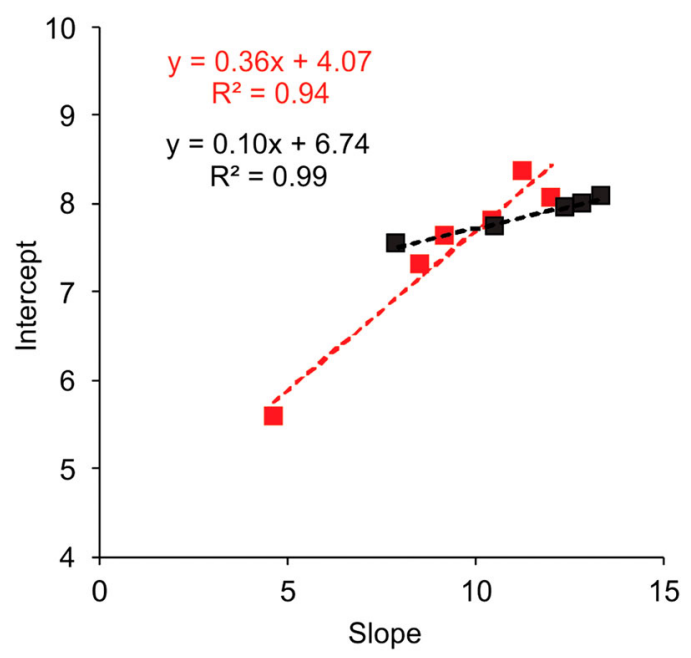

Figure 4. Relationship between slope and intercept of LMWL from GNIP stations encompassed in Group 01 (black) and Group 02 (red). 
equation of the regional meteoric water line for Group 3 is $\delta^{2} \mathrm{H}=(7.67 \pm 0.19) \delta^{18} \mathrm{O}+$ (10.59 \pm 0.96$)(r=0.95, a=0.05$ and $n=172)$ (Figure 3$)$. The proximity to moisture sources, represented by the Atlantic Ocean, explains these values.

Using the ANCOVA test [49], the differences between the LMWLs from the three groups $(1,2,3)$ indicate distinct precipitation events and isotopic evolution for the conditions of $F=20.05, F_{0.05(1), 2,1079} \approx 3.01$, the null hypothesis is rejected, and the LMWLs are not equal.

\subsection{Monthly record - isotope effects}

The isotopic composition of precipitation is marked by important seasonal variations for the weighted mean $\delta^{18} \mathrm{O}$ values (Figure 3). The depleted values pertain to the precipitation events during the late summer (March-April) when the region is affected by the influence of the SACZ. The enhanced $\delta^{18} \mathrm{O}$ values refer to the winter season precipitation events when the region is influenced by the extratropical circulation.

Values of $\delta^{18} \mathrm{O}$ from Group 1 and Group 2 are fairly correlated to the precipitation amount $(r=-0.46$, with $a=0.05, n=351$, and $r=-0.49$, with $a=0.05$ and $n=523$, respectively), while for Group 3 no correlation is observed between $\delta^{18} \mathrm{O}$ and the precipitation amount (Figure 3).

As expected to occur in tropical regions where air temperature plays a minor role in isotopic variability, no correlation is observed between $\delta^{18} \mathrm{O}$ and temperature for samples from the three groups. But for all groups, a fairly negative correlation exists between air temperature and $\delta^{2} \mathrm{H}$ at $a=0.05$ (respectively for Groups 1, 2 and 3: $r=-0.149$ for $n=$ $351, r=-0.126$ for $n=523$ and $r=-0.244$ for $n=172$ ).

Some aspects of Rayleigh distillation associated with the isotopic composition of precipitation have been described by several authors [6-9,17-19] in terms of variations according to the geographical position of the sampling point (latitude, continentality and altitude). The annual weighted mean values for $\delta^{18} \mathrm{O}$ show a good correlation with latitude $(r=0.69$, with $a<.05)$ and longitude $(r=0.77$, with $a<0.05)$, indicating the existence of a longitudinal effect. Considering the distance of the Atlantic Ocean directly related to the longitude of the sampling point, the effect of continentality was observed. Located further away from the ocean, the isotopic composition of precipitation of the GNIP station is more depleted.

In terms of altitude - despite the observed negative correlation - this effect is not significant ( $r=-0.45$, with $a=0.1$ ), probably due to topographic conformation of the Brazilian territory where no great differences in altitude are observed which could represent barriers for the displacement of vapour masses.

During the period when the SACZ is more active (December-January-February) (Figure 1), correlations with isotopic effects related to the Rayleigh distillation process are enhanced. Latitude and longitude (continentality) effects present a good correlation with values of $\delta^{18} \mathrm{O}$ (respectively, $r=0.72$, with $a<0.05$, and $r=0.79$, with $a<0.05$ ), probably associated to rain-out effects observed during the displacement of the SACZ over the Brazilian territory. It should be noticed that the correlation factors are not strong $(r=0.52$, with $a<0.05$ for latitude, and $r=0.25$, with $a=0.1$ for longitude) during the period when the SACZ is not active (June-July-August). 


\subsection{Seasonal variation in monthly record}

The isotopic composition is marked by important seasonal variations for the weighted mean $\delta^{18} \mathrm{O}$ values (Figure 3). For GNIP stations from Group 1, during the rainy season (JanuaryApril) precipitation was depleted compared to the dry season, and observed differences between wet and dry season were about $-4 \%$. For Group 2, depleted values were associated with the precipitation events during the late summer (March-April), while during the winter (dry season) more enriched values were observed, wherein differences could reach up to $-7 \%$ o. Seasonal variations in the southern region of Brazil are marked by an inverse behaviour despite small variations in precipitation; more depleted values are observed during the dry season, while during rainy months, precipitation is more enriched up to + $4 \%$ (Figure 3). Annual weighted mean values for $\delta^{18} \mathrm{O}$ and $\delta^{2} \mathrm{H}$ showed a trend indicating latitude effects: more depleted precipitation is observed towards south of Brazil (Group 3), while enriched precipitation in the northeastern region (Group 1).

Seasonal variations in $d$-excess for GNIP stations from Group 1 are marked by an increase in $d$-excess from January to July (from 6 to $12 \%$ ) followed by a decrease in the dry season. For Group 2, $d$-excess values are about $10 \%$ during wet season, while during the dry season, values of $d$-excess can reach $14 \%$. In the southern region of Brazil during the wet season, $d$-excess values are about 12-14\%o, while about 10-11\%o during dry season. Despite differences observed in the precipitation amount in the southern (Group 3) and southeastern (Group 2) regions of Brazil, atmospheric processes and vapour sources could be related.

Interpolation of monthly weighted isotopic composition from GNIP stations in Brazil, including those located in the Amazon region has allowed the evaluation of spatial and seasonal variations on precipitation isotopologues (Figure 5) and the comparison with the large regional climate figures, such as ITCZ and SACZ. A well-marked latitude influence in precipitation isotopic composition was observed specially during the wet summer season (November-March), when more enriched ${ }^{18} \mathrm{O}$ concentrations are observed in NE Brazil, while towards the south, depletion in ${ }^{18} \mathrm{O}$ is detected. Precipitation isotope variations observed over NE Brazil are mainly related to the influence of ITCZ movement along the year, as reported by Różanski and Araguás-Araguás [54], as well as due to the vicinity of the Atlantic Ocean which acts as the more prominent vapour source.

It should be noticed that a NW-SE elongated band of more depleted precipitation is observed during the wet season (Figure 5), presenting a similar spatial distribution to the SACZ (Figure 1), which is associated with the South Atlantic subtropical anticyclone. This anticyclone operative during the summer season is responsible for bringing moisture over the continent. The anticyclone associated with cold fronts coming from the south is linked with the SACZ and generates precipitation across the eastern part of Brazil. It is responsible for an enhanced convective activity system and exhibits more depleted ${ }^{18} \mathrm{O}$ in precipitation.

Displacement of the South Atlantic subtropical anticyclone towards the east during the winter and dry season interrupts the moisture transportation to the NE and centre of Brazil resulting in lower precipitation rates. However, rain events are normally associated with sporadic extratropical cold fronts coming from the south. This causes ${ }^{18} \mathrm{O}$ enrichment in precipitation up to $+3 \%$ in $\delta^{18} \mathrm{O}$ during the winter season as observed in the central region. 


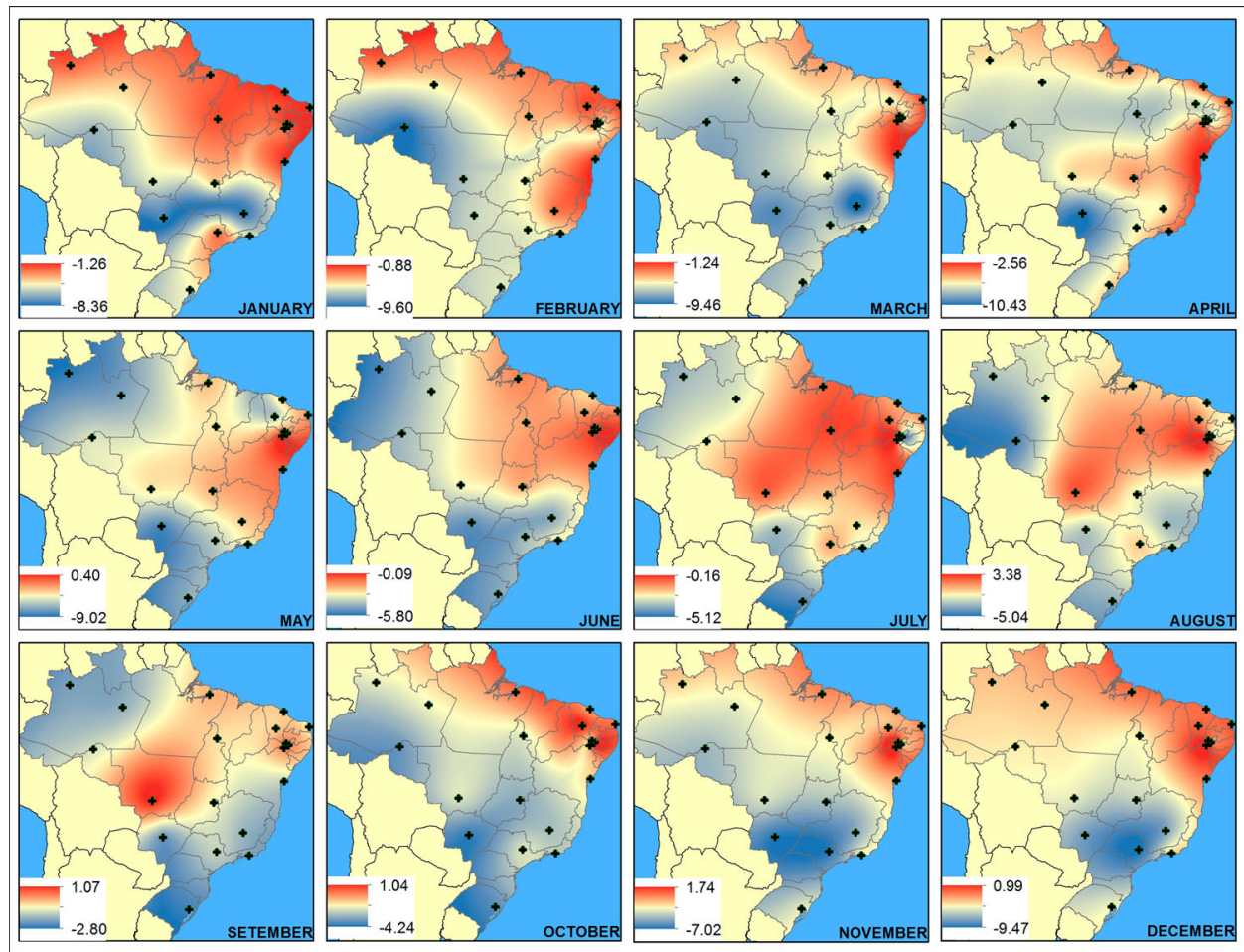

Figure 5. Monthly variations in weighted mean values for $\delta^{18} \mathrm{O}$. Isotopic composition of GNIP stations located in Amazonian region of Brazil was used to interpolation.

\subsection{Daily record}

The daily rain samples collected from February 2014 to February 2015 in the Rio Claro GNIP station ( $n=51$ samples) showed a large amount of variability in the isotopic composition (supplementary material, Table 2). The values for $\delta^{2} \mathrm{H}$ were in the range between -136.0 and $+23.1 \%$ with $-22.8 \pm 32.34 \%$ on average, weighted mean $-32.1 \%$; $\delta^{18} \mathrm{O}$ values ranged from -18.36 to $+0.82 \%$ o, $-4.47 \pm 3.96 \%$ on average, weighted mean $-5.72 \%$ o. The $d$-excess varied from 1.57 to $22.92 \%$ with an average of $12.93 \pm 4.32 \%$ o. The meteoric water line based on isotopic composition of daily samples precipitation shows a similar inclination of the line calculated based on monthly composite sample (8.10 and 7.98, respectively), while interception values are different (13.41 and 12.34, respectively). Statistical analysis of the LMWL from monthly and daily samples from Rio Claro (ANCOVA test) indicates that $F=0.002$, and as $F_{0.05(1), 1,100} \approx 253$, the null hypothesis is accepted, and the LMWLs are equal. It represents the same precipitation processes and isotopic evolution despite the distinct temporal series for daily samples (2014-2015) and monthly samples (2012-2013) (Figure 6 and supplementary material, Table 1).

Although no good correlation was found between precipitation amount and $\delta^{18} \mathrm{O}$ values $(r=-0.26, a=0.05$ and $n=42)$, more ${ }^{18} \mathrm{O}$ enriched concentrations were observed during the dry season (May to August), while the most ${ }^{18} \mathrm{O}$ depleted events occur during rainy season (November to February) (Figure 7). 


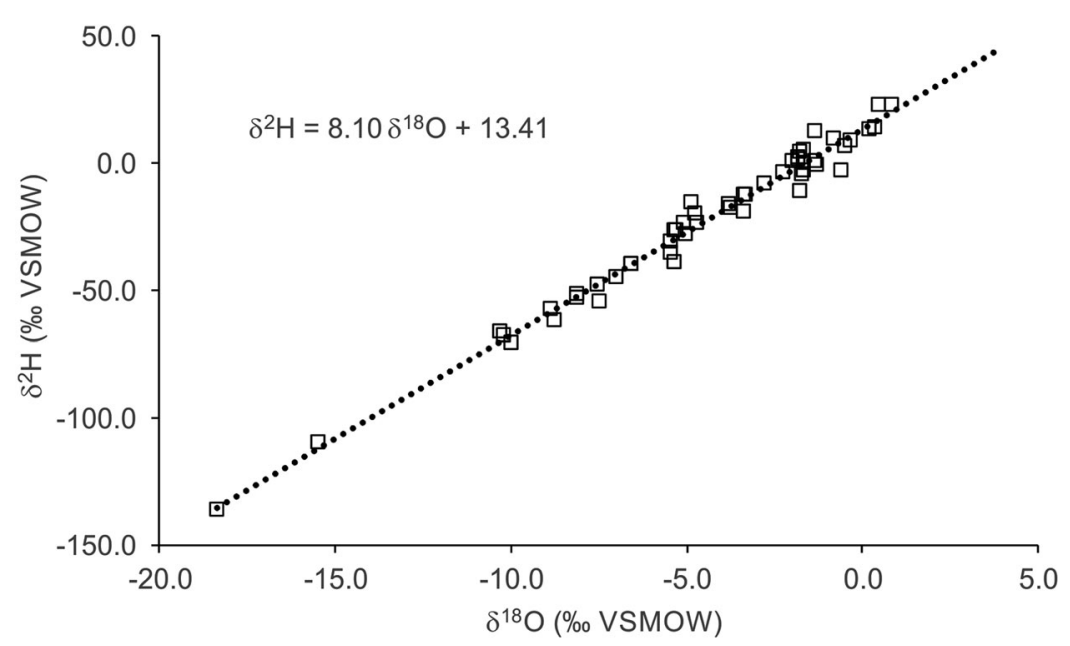

Figure $6 . \delta^{18} \mathrm{O}$ versus $\delta^{2} \mathrm{H}$ and local meteoric water line based on daily samples from Rio Claro GNIP.

The 48-hour back trajectories for every rainy day at the Rio Claro GNIP station showed three distinctly different directions associated with the movement of air masses (Figure 8). The main direction is associated with air masses coming from the Atlantic Ocean; in addition, part of the precipitation events are related to air masses coming from the Amazon Basin. During dry seasons, the extratropical circulation regime is actively associated with migratory cyclones along the subtropical Atlantic coast, which are responsible for the movement of wet cold fronts over the continent where hot dry air masses are stationed. As a result, significant differences on isotopic composition from precipitation collected during the wet and dry seasons were observed.

During the wet season, $\delta^{18} \mathrm{O}$ varied from -18.36 to $+0.37 \%$, arithmetic mean $-5.20 \pm$ $4.25 \%$, weighted mean $-6.53 \%$ o. The $\delta^{2} \mathrm{H}$ values varied from -136.0 to $+14.2 \%$, arithmetic mean $-29.1 \pm 34.1 \%$ o, weighted mean $-38.9 \%$, and the $d$-excess varied from 1.57 to + $22.92 \%$, arithmetic mean $12.42 \pm 4.48 \%$ o, weighted mean $13.21 \%$ o. The meteoric water line for this period shows a regression equation of $\delta^{2} H=(7.95 \pm 0.18) \delta^{18} \mathrm{O}+(12.19 \pm 1.26)$

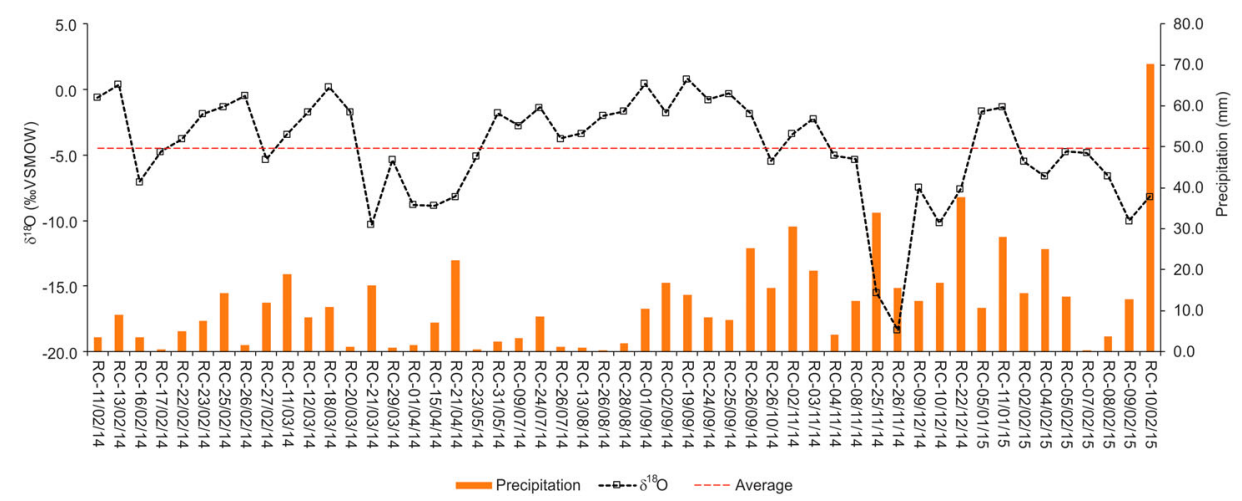

Figure 7. Daily variations for $\delta^{18} \mathrm{O}$ and precipitation in Rio Claro GNIP station for the period 2014-2015/ February. 


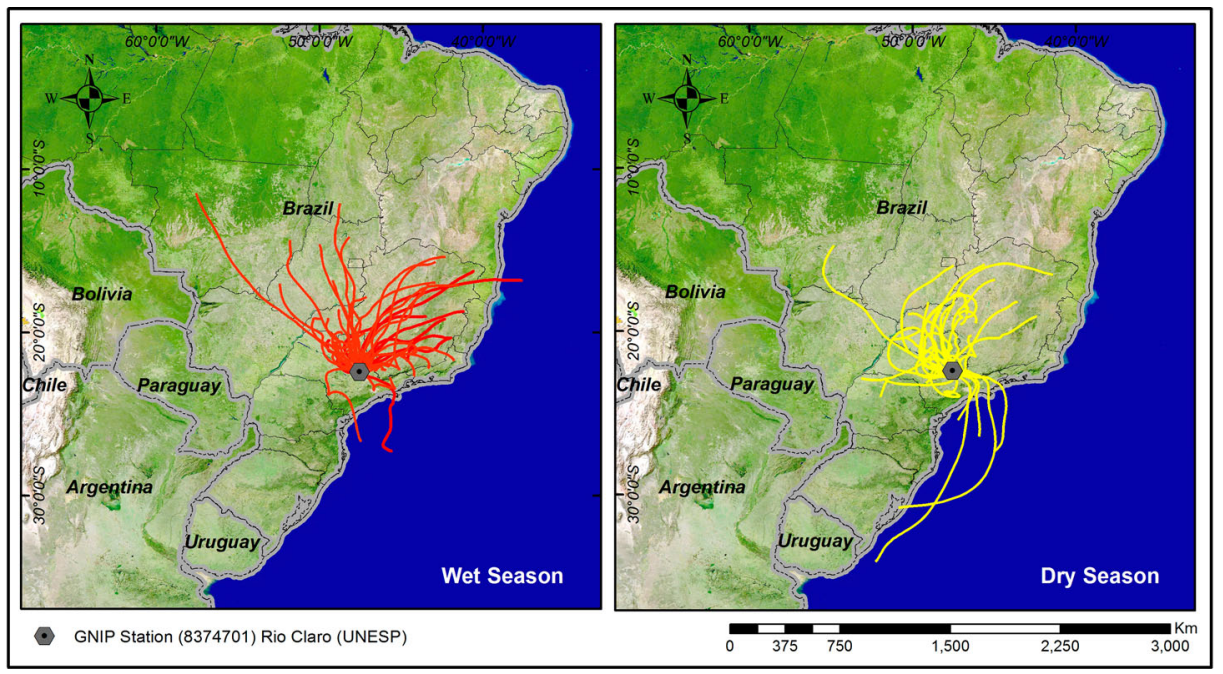

Figure 8. Hysplit trajectories calculated for wet season (left) and dry season (right). The moisture source is related to Atlantic Ocean with important contribution from Amazonian Basin during wet season.

$(r=0.99, a=0.05$ and $n=33)$, presenting inclination similar to GMWL, and a value of $d$-excess $>10$, probably associated with the large humidity gradients along the trajectory, which in turn, enhance the kinetic fractionation associated with re-evaporation processes.

During the dry season, the precipitation in average is more positive in $\delta^{18} \mathrm{O}$ and $\delta^{2} \mathrm{H}$ compared with the wet season: $\delta^{18} \mathrm{O}$ varied from -8.86 to $+0.82 \%$, arithmetic mean $-3.13 \pm 3.00 \%$, weighted mean $-3.06 \%$; $\delta^{2} \mathrm{H}$ varied from -62.0 to $+23.1 \%$, arithmetic mean $-11.19 \pm 25.7 \%$, weighted mean $-9.81 \%$, and the $d$-excess varied from +3.40 to $+19.40 \%$, arithmetic mean $13.88 \pm 3.92 \%$, weighted mean $14.65 \%$ o. The meteoric water line shows a regression equation of $\delta^{2} \mathrm{H}=(8.43 \pm 0.30) \quad \delta^{18} \mathrm{O}+(15.39 \pm 1.30)$ $(r=0.97$, with $a=0.05$ and $n=18)$ for this period. Effects of vapour recirculation and low humidity seem to have an influence on the $d$-excess being greater than the GMWL [69,17-19].

Correlation between meteorological variables (ground and trajectory-based) and the isotopic composition of rainfall $\left(\delta^{2} \mathrm{H}\right.$ and $\left.\delta^{18} \mathrm{O}\right)$ were evaluated based on three distinct vapour residence times $(48,120$ and $240 \mathrm{~h})$. The isotopic composition $\left(\delta^{2} \mathrm{H}\right.$ and $\delta^{18} \mathrm{O}$ ) presents a positive correlation with mix depth and a negative correlation with precipitation along the trajectory. For residence times of 120 and $240 \mathrm{~h}$, a negative correlation with relative humidity along the trajectory is observed (supplementary material, Table 3). No relevant correlation was found with the other meteorological variables. Strong correlation was observed between the overall relative humidity along the trajectory and the trajectory-based meteorological variables. This resulted in removing this variable from the regression model due to the effect of multicollinearity.

The linear regression model considers five variables to better explain variations for $\delta^{18} \mathrm{O}, \delta^{2} \mathrm{H}$ and $d$-excess, and a summary of the results is presented in the supplementary material, Table 4 . These regression models are able to explain the majority of the variations 
on the isotopic composition of precipitation presenting a correlation coefficient $(r)$ of about $0.60,0.60$ and 0.45 for $\delta^{18} \mathrm{O}, \delta^{2} \mathrm{H}$ and $d$-excess, respectively. No great differences in correlation coefficients were observed for the different trajectory vapour residence times in atmosphere, but changes in variables should be noticed.

The variables are mostly related to atmospheric trajectories, encompassing variations on precipitation and mix depth along the trajectory to explain variations in isotopic composition, indicating that the processes occurring along the transport of vapour over the ocean and continent areas are responsible for the observed variations on the isotopic composition of precipitation, while variations in $d$-excess are associated with mix depth and wind direction. Mix depth reveals the importance of convective activity in the isotopic composition of precipitation. It should be emphasized that, despite small variations in
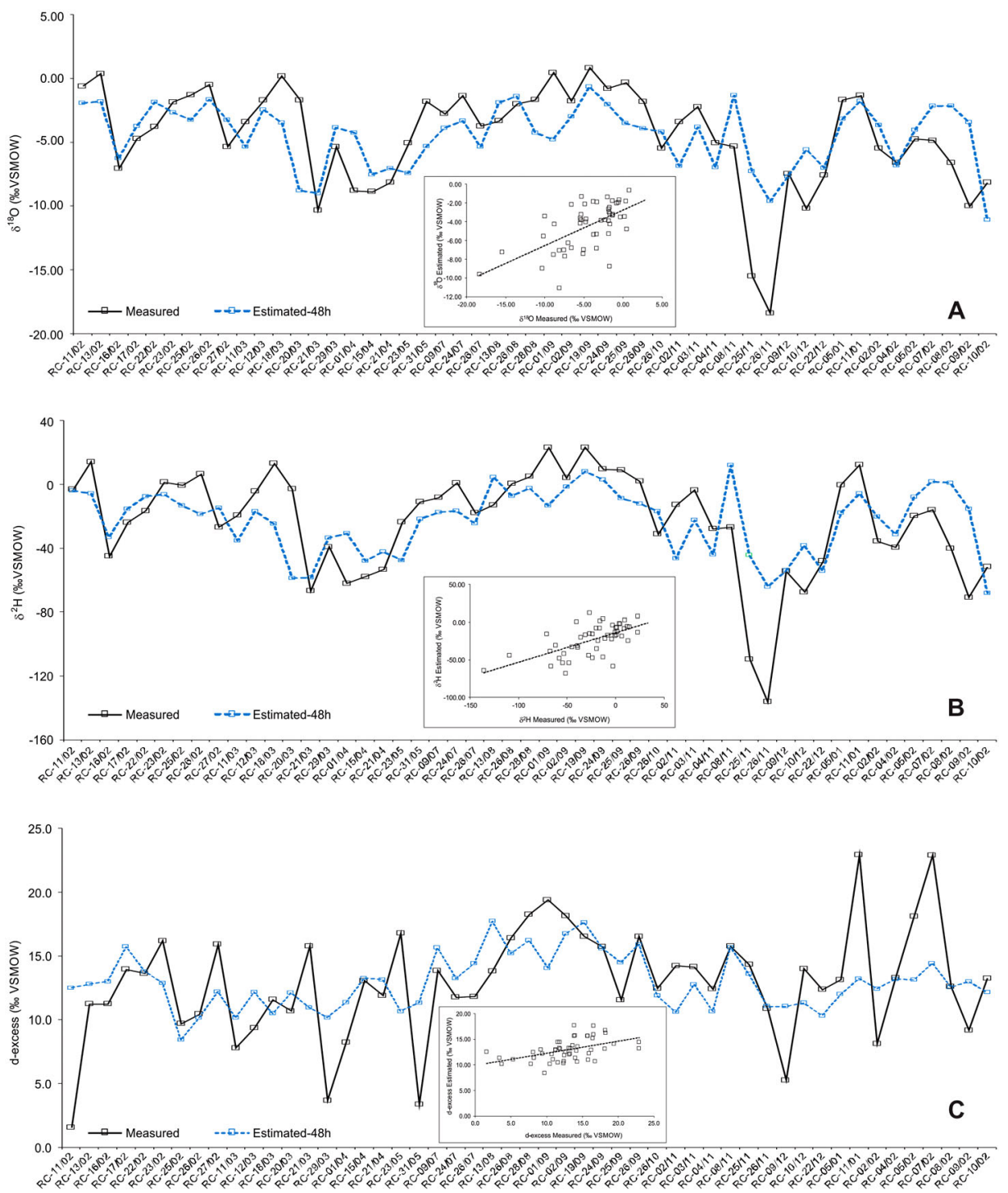

Figure 9. Measured versus calculated values of $\delta^{18} \mathrm{O}(\mathrm{A})$, of $\delta^{2} \mathrm{H}(\mathrm{B})$, and $d$-excess (C). 
predictable variables for the models, the results are very similar and they are not dependent on vapour residence time in atmosphere.

Despite the regression model being able to reproduce the observed values of $\delta^{18} \mathrm{O}$ and $\delta^{2} \mathrm{H}$, it should be noticed that the model tends to underestimates values for more depleted precipitation events (Figure 9 and supplementary material, Table 4).

For $d$-excess values, these models are not so efficient to reproduce the values, probably because $d$-excess is not correlated with any of the meteorological variables considered in this study (supplementary material, Table 3 ).

The differences between the modelled and measured values observed during the wet season, when the SACZ is intensified over the southern portion of the Brazilian territory, could be related to the effects of the convective system associated with this important meteorological feature $[26,27]$. More robust variables should be added to the model in order to distinguish convective and stratiform precipitations.

\section{Conclusions}

Observed regional and temporal variations in isotopic precipitation are associated with important features operating over the eastern part of Brazil. On an annual basis, latitude effects on the isotopic composition of precipitation are observed, resulting in isotopically more enriched precipitation over the NE region (Group 1), while towards the South (Groups 2 and 3), precipitation is more depleted, up to $-2 \%$ for $\delta^{18} \mathrm{O}$.

Temporal variations in the NE region are related to meridional migration of the ITCZ towards the south which results in a depletion in the isotopic content of precipitation during the wet season associated with an increase in the precipitation amount. In the $\mathrm{SE}$, the SACZ produces isotopically more depleted precipitation, up to $-7 \%$ o for $\delta^{18} \mathrm{O}$, compared to the dry season during the period when the SASM is active. Despite these seasonal variations observed along the studied region of the Brazilian territory, associated with variations on precipitation regimes, a fair correlation between isotopic composition and precipitation is observed, particularly for Groups 1 and 2 while no amount effect is observed in precipitation for Group 3.

Effects of the SACZ on isotopic composition of precipitation were observed during the wet season, represented by a NW-SE elongated band of more depleted precipitation associated with cold fronts coming from the South responsible by an enhanced convective activity system.

The more recent monitoring programme carried out in Rio Claro (February 2014/February 2015) indicates a large variability in the isotopic composition of precipitation, aligning along the LMWL based on monthly composite samples. No correlation was found between precipitation amount and isotopic composition, despite the distribution of more depleted events during wet season and enriched precipitation along dry season.

The origin of vapour, tracked using HYSPLIT, indicates three distinct directions, most of them coming from the Atlantic Ocean. In addition, parts of precipitation are related to air masses coming from the Amazon Basin although no temporal association with directions is observed.

The linear multiple regression model indicates that the processes occurring along the vapour transportation trajectory are more effective to explain variations in the isotopic composition in precipitation, although no relationship is observed related to vapour 
origin and residence time in atmosphere. The main meteorological parameters related to $\delta^{18} \mathrm{O}$ and $\delta^{2} \mathrm{H}$ variations are precipitation amount along the trajectory and mix depth, while for $d$-excess wind direction and mix depth are the variables. The presence of mix depth in all models indicates the influence of the type of rain, convective or stratiform, on their isotopic composition.

\section{Acknowledgements}

The authors would also thank Dr Gerhard Strauch, Editor-in-Chief of Isotopes in Environmental and Health Studies, and Dr B.P. Singh and two anonymous reviewers for their comments, which have substantially improved this manuscript.

\section{Disclosure statement}

No potential conflict of interest was reported by the authors.

\section{Funding}

This project was supported by the International Atomic Energy Agency (grant CRP-19747 to DG under the initiative 'Stable isotopes in precipitation and paleoclimatic archives in tropical areas to improve regional hydrological and climatic impact models'). The sampling programme in Rio Claro was supported by Pró Reitoria de Pesquisa - Univ. Est. Paulista (Primeiros Projetos -edital 11/2012 PROPE): The authors would like to thank FAPESP for the scholarship provided for the second author under the process 2013/06704-0, and to Conselho Nacional de Desenvolvimento Científico e Tecnológico (CNPq) for the scholarship provided for the third author, under the process 142070/2013-0.

\section{ORCID}

Didier Gastmans (D) http://orcid.org/0000-0002-1340-3373

\section{References}

[1] Pezza A, Simmonds I. The first South Atlantic hurricane: unprecedented blocking, low shear and climate change. Geophys Res Lett. 2005;32:L15712. DOI:10.1029/2005GL023390.

[2] Marengo JA, Nobre C, Tomasella J, et al. The drought of Amazonia in 2005. J Climate. 2007;21:495-516.

[3] Valverde MC, Marengo JE. Mudanças na circulação atmosférica sobre a América do Sul para cenários futuros de clima projetados pelos modelos globais do IPCC R4 [Changes in atmospheric circulation over South America for futures scenarios projected using IPCC R4 global models]. Rev Bras Meteorol. 2010;25:125-145. Portuguese.

[4] Bowen G. Statistical and geostatistical mapping of precipitation water isotope ratios. In: West JB, Bowen GJ, Dawson TE, Tu KP, editors. Isoscapes: understanding movement, pattern, and process on Earth through isotope mapping. Dordrecht: Springer Science; 2010. p. 139-160.

[5] Craig H. Standards for reporting concentrations of deuterium and oxygen-18 in natural waters. Science. 1961;133:1833-1834.

[6] Dansgaard W. Stable isotopes in precipitation. Tellus. 1964;16:436-468. 
[7] Gat JR. Some classical concepts on isotope hydrology. In: Aggarwal PK, Gat JR, Froehlich KF, editors. Isotopes in the water cycle: past, present and future of a developing science. Dordrecht: Springer; 2005. p. 127-139.

[8] Rożanski K, Araguás-Araguás L, Gonfiantini R. Isotopic patterns in precipitation. In: Swart PK, Lohmann KC, Mckenzie J, Savin S, editors. Climate change in continental isotopic records. Washington (DC): American Geophysical Union; 1993. p. 1-36 (Vol. 78; Geophysical Monograph Series).

[9] Clark ID, Fritz P. Environmental isotopes in hydrogeology. Boca Raton (FL): Lewis Publishers; 1997.

[10] Sánchez-Murillo R, Birkel C, Welsh K, et al. Key drivers controlling stable isotope variations in daily precipitation of Costa Rica: Caribbean Sea versus Eastern Pacific Ocean moisture sources. Quat Sci Rev. 2016;131:250-261.

[11] Kurita N, Ichiyanagi K, Matsumoto J, et al. The relationship between the isotopic content of precipitation and the precipitation amount in tropical regions. J Geochem Explor. 2009;102: 113-122.

[12] Vimeux F, Gallaire R, Bony $S$, et al. What are the climate controls on $\delta D$ in precipitation in the Zongo Valley (Bolivia)? Implications for the Illimani ice core interpretation. Earth Planet Sci Lett. 2005;240:205-220.

[13] Wu J, Ding Y, Ye B, et al. Spatio-temporal variation of stable isotopes in precipitation in the Heihe River Basin, Northwestern China. Environ Earth Sci. 2010;61:1123-1134.

[14] Wu H, Zhang X, Xiaoyan L, et al. Seasonal variations of deuterium and oxygen-18 isotopes and their response to moisture source for precipitation events in the subtropical monsoon region. Hydrol Process. 2015;29:90-102.

[15] Kurita N. Water isotopic variability in response to mesoscale convective system over the tropical ocean. J Geophys Res Atmos. 2013;118:10376-10390.

[16] Aggarwal PK, Romatscheke U, Araguas-Araguas LJ, et al. Proportions of convective and stratiform precipitation revealed in water isotope ratios. Nature. 2016. DOI:10.1038/NGEO2739.

[17] Aggarwal PK, Alduchov OA, Froehlich KO, et al. Stable isotopes in global precipitation: a unified interpretation based on atmospheric moisture residence time. Geophys Res Lett. 2012;39: L11705. DOI:10.1029/2012GL051937.

[18] Salati E, Dall'Olio A, Matsui E, et al. Recycling of water in the Amazon basin: an isotopic study. Water Resour Res. 1979;15:1250-1258.

[19] Matsui E, Salati E, Ribeiro M, et al. Precipitation in the Central Amazon Basin: the isotopic composition of rain and atmospheric moisture at Belem and Manaus. Acta Amaz. 1983;13:307-369.

[20] Gat JR, Matsui E. Atmospheric water balance in the Amazon Basin: an isotopic evapotranspiration model. J Geophys Res. 1991;96(D7):13179-13188.

[21] Draxler RR, Rolph GD. HYSPLIT (HYbrid Single-Particle Lagrangian Integrated Trajectory) Model access via NOAA ARL READY Website (http://www.arl.noaa.gov/HYSPLIT.php). NOAA Air Resources Laboratory, College Park, MD, 2011.

[22] Reboita MS, Gan MA, Rocha RP, et al. Regimes de precipitação na América do Sul: uma revisão bibiligráfica [Precipitation regims over South America: a review]. Rev Bras Meteorol. 2010;25:185-204. Portuguese.

[23] Grimm AM. The El Niño impact on the summer monsoon in Brazil: regional processes versus remote influences. J Climatol. 2003;16:263-280.

[24] Climate Prediction Center Merged Analysis of Precipitation (CMAP) [cited 2015 Oct 10]. Available from: http://www.cpc.ncep.noaa.gov/products/global_precip/html/wpage.cmap.html.

[25] Xie P, Arkin PA. Global precipitation: a 17-year monthly analysis based on gauge observations, satellite estimates, and numerical model outputs. Bull Am Meteorol Soc. 1997;78:2539-2558.

[26] Vuille $M$, Bradley RS, Werner $M$, et al. Modeling $\delta^{18} \mathrm{O}$ in precipitation over the tropical Americas: 1 . Interannual variability and climatic controls. J Geophys Res. 2003;108:505. DOI:10.1029/ 2001JD002038.

[27] Vuille $M$, Werner $M$. Stable isotopes in precipitation recording South American summer monsoon and ENSO variability: observations and model results. Clim Dyn. 2005;25:401-413. 
[28] Carvalho LMV, Jones C, Liebmann B. The South Atlantic convergence zone: intensity, form, persistence, and relationships with intraseasonal to interannual activity and extreme rainfall. J Climatol. 2004;17:88-108.

[29] Matsuyama H, Miyoaka K, Masuda K. Year-to-year variations of the stable isotopes in precipitation in February at Cuiabá, located on the northern fringe of Pantanal, Brazil. J Hydrometeorol. 2005;6:324-329.

[30] Gan MA, Rao VB. Surface cyclogenesis over South America. Mon Weather Rev. 1991;119:12931302.

[31] Vera CS, Vigliarolo PK, Berbery EH. Cold season synopticscale waves over subtropical South America. Mon Weather Rev. 2002;130:684-699.

[32] Cruz FW, Karmann I, Viana Jr O, et al. Stable isotope study of cave percolation waters in subtropical Brazil: implications for paleoclimate inferences from speleothems. Chem Geol. 2005;220:245-262.

[33] Mechoso CR, Lyons SW, Spahr JA. The impact of sea surface temperature anomalies on the rainfall over northeast Brazil. J Climatol. 1990;3:812-826.

[34] Hastenrath S, Greischar L. Circulation mechanisms related to northeast Brazil rainfall anomalies. J Geophys Res. 1993;98:5093-5102.

[35] Marengo JA, Hastenrath S. Case studies of extreme climatic events in the Amazon basin. J Climatol. 1993;6:617-627.

[36] Vuille M, Bradley RS, Keimig F. Climatic variability in the Andes of Ecuador and its relation to tropical Pacific and Atlantic sea surface temperature anomalies. J Climatol. 2000;13:2520-2535.

[37] Aceituno P. On the functioning of the Southern Oscillation in the South American sector. Part I: Surface climate. Mon Weather Rev. 1988;116:505-524.

[38] Vuille M. Atmospheric circulation over the Bolivian Altiplano during dry and wet periods and extreme phases of the Southern Oscillation. Int J Climatol. 1999;19:1579-1600.

[39] Garreaud RD, Aceituno P. Interannual rainfall variability over the South American Altiplano. J Climatol. 2001;14:2779-2789.

[40] Grimm AM. How do la Niña events disturb the summer monsoon system in Brazil? Clim Dyn. 2004;22:123-138.

[41] Oyama MD, Nobre CA. A new climate-vegetation equilibrium state for tropical South America. Geophys Res Lett. 2003;30:2199. DOI:10.1029/2003GL018600.

[42] Koster RD, Dirmeyer PA, Guo Z, et al. Regions of strong coupling between soil moisture and precipitation. Science. 2004;305:1138-1140.

[43] Garreaud RD, Wallace JM. Summertime incursions of midlatitude air into subtropical and tropical South America. Mon Weather Rev. 1998;126:2713-2733.

[44] Seluchi ME, Marengo JA. Tropical-midlatitude exchange of air masses during summer and winter in South America: climatic aspects and examples of intense events. Int J Climatol. 2000;20:1167-1190.

[45] Chou C, Neelin JD. Mechanisms limiting the southward extent of the South American summer monsoon. Geophys Res Lett. 2001;28:2433-2436.

[46] Global Network on Isotopes in Precipitation (GNIP). Vienna: International Atomic Energy Agency (IAEA). [cited 2012 Jul 14]. Available from: http://www-naweb.iaea.org/napc/ih/lHS_resources_ gnip.html.

[47] IAEA (International Atomic Energy Agency) IAEA/GNIP precipitation sampling guide. 2014. Accessible at: http://www-naweb.iaea.org/napc/ih/documents/other/gnip_manual_v2.02_en_hq.pdf.

[48] Gröning M, Lutz HO, Roller-Lutz Z, et al. A simple rain collector preventing water re-evaporation dedicated for $\delta^{18} \mathrm{O}$ and $\delta^{2} \mathrm{H}$ analysis of cumulative precipitation samples. J Hydrol. 2012;448449:195-200.

[49] Zar JH. Biostatistical analysis. 5th ed. Upper Saddle River (NJ): Prentice Hall; 2010.

[50] ESRI. ArcGIS desktop: release 10.2. Redlands (CA): Environmental Systems Research Institute; 2015.

[51] National Centers for Environmental Prediction/National Weather Service/NOAA/U.S. Department of Commerce. NCEP GDAS Satellite Data. Research Data Archive at the National Center for Atmospheric Research 2009. Computational and Information Systems Laboratory. [cited 2016 July 06]. Available from: http://rda.ucar.edu/datasets/ds735.0/. 
[52] Ayres M, Ayres Jr M, Ayres DL, et al. BioEstat. Versão 5.0, Sociedade Civil. Mamirauá, MCT - CNPq, 2007.

[53] Singh BP. New approach for the analysis of isotopic composition in precipitation globally. Hydrol Curr Res. 2016;7:225. DOI:10.4172/2157-7587.1000225.

[54] Różanski K, Araguás-Araguás L. Spatial and temporal variability of stable isotope composition of precipitation over the South American continent. Bull Inst Fr Étud Andin. 1995;24:379-390. 